MINERALOGIA, 41, No 1-2: 3-9 (2010)

DOI: 10.2478/v10002-010-0007-y

www.Mineralogia.pl

MineRalogical Society of Poland

Polskie TOWARZYSTWO MINERALOgICZNE

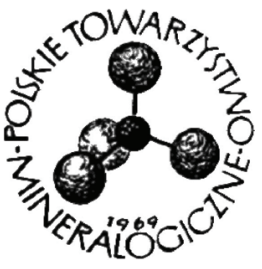

Original paper

\title{
Xenotime from the Podwiśniówka mine pit, Holy Cross Mountains (South-Central Poland)
}

\author{
Zdzisław M. MIGASZEWSKI, Agnieszka GAŁUSZKA \\ Jan Kochanowski University, Institute of Chemistry, Geochemistry and the Environment Div., \\ 15 G Świętokrzyska St., 25-406 Kielce, Poland \\ e-mail: zmig@ujk.kielce.pl; aggie@ujk.kielce.pl \\ * Corresponding author
}

Received: March 31, 2010

Received in revised form: October 12, 2010

Accepted: October 29, 2010

Available online: November 20, 2010

Abstract. This report presents the results of petrographical and mineralogical (optical microscopy, SEM/EDS) study of xenotime derived from the Upper (Middle?) Cambrian rocks (Wiśniówka Sandstone Fm.) of the abandoned Podwiśniówka mine pit. This is the first work on this mineral from the Holy Cross Mts. The authigenic xenotime occurs primarily as overgrowths around/on zircon in siliciclastic rocks. Moreover, this mineral is characterized by the large size of the overgrowths reaching $50 \mu \mathrm{m}$ long and $20 \mu \mathrm{m}$ wide. The presence of pyritecoated zircon/xenotime aggregates indicates that the xenotime formed prior to hydrothermal quartz-pyrite mineralization. The apparent lack of xenotime and vein pyrite in the tuff-bearing series, compared to the other two series displaying hydrothermal signature (pyrite, hematite, nacrite, jarosite), as well as considerable variations of the xenotime overgrowths in size and morphology, and their dominant irregular patchy-zonal microtexture may provide evidence for direct precipitation of this mineral from hydrothermal fluids.

Key-words: xenotime, Wiśniówka Sandstone Fm., Podwiśniówka mine pit, Holy Cross Mts, Poland, TESZ

\section{Introduction}

Xenotime $\left(\mathrm{YPO}_{4}\right)$ is a common accessory mineral that occurs in a wide variety of igneous, metamorphic, hydrothermal and sedimentary environments (e.g. Wark, Miller 1993; Förster 1998; England et al. 2001; Rasmussen et. al 2001, 2007; Kositcin et al. 2003; 
Vallini et al. 2005; Richter et al. 2006; Stanisławska, Michalik 2008; Harlov et al. 2008; Hetherington et al. 2008). This mineral has found application in geochronology of various sedimentary and diagenetic processes in siliciclastic rocks (McNaughton et al. 1999; Kositcin et al. 2003; Rasmussen, 2005; Rainbird et al. 2006; Hetherington et al. 2008). These deposits are commonly characterized by the presence of authigenic xenotime that usually forms pyramidal, syntaxial outgrowths from detrital zircon grains (Rasmussen 1996). Along with aluminophosphate and phosphate minerals (florencite, crandallite, goyazite, apatite) xenotime represents an important global sink for oceanic P, Y and the HREE (Rasmussen 1996).

This report presents the first results derived from optical microscopy and SEM/EDS analyses performed on the xenotime and zircon as well as on their host rocks from the Upper (Middle?) Cambrian succession of the abandoned Podwiśniówka mine pit, Holy Cross Mts, Poland. The principal objective of this study was to characterize the unique occurrence of xenotime in the Holy Cross Mts and propose a concept of the origin of this mineral based on petrographical and mineralogical data. This is a part of a larger ongoing investigation aiming at elucidating various aspects of ore and gangue mineralization and acid mine drainage (AMD) in the Wiśniówka mining area.

\section{Study area location and geologic framework}

The study area comprises the abandoned Podwiśniówka mine pit (Fig. 1A). This is the easternmost part of the large Wiśniówka massif which forms the western part of the Łysogóry Block in the Holy Cross Mountains. This Paleozoic structure is a part of the Trans-European Suture Zone (TESZ). Highly complex geologic setting of the study area is the subject of much controversy (e.g. Żylińska et al. 2006 and references therein). The Podwiśniówka mine pit bedrock consists of the Upper Cambrian (Furongian) series composed of quartzites, quartzitic sandstones with clayey shale, tuff/tuffite and bentonite interbeds. These rocks make up the Wiśniówka Sandstone Formation. Żylińska et al. (2006) suggests that the rocks from Podwiśniówka may be of uppermost Middle Cambrian age.

The mine pit is partly filled with a shallow acid pond (Migaszewski et al. 2007a, 2008). The most exposed western wall consists of three rock series: (i) the southern series consisting of northerly-dipping, fine-bedded quartzites, in places with numerous tuffite and bentonite interbeds, (ii) the central (pyrite-bearing) series consisting of steeply-dipping, medium-bedded quartzites, quartzitic sandstones and siltstones with subordinate clayey shales, and (iii) the northern series composed of non-bedded hematite-goethite quartzites passing northward into hydrothermally metamorphosed quartzites, locally quartzite-quartz breccias (Fig. 1B).

The rocks of the central series contain scattered and vein crypto- to microcrystalline pyrite associated with secondary goethite accumulations. In some places, quartzite-quartzpyrite breccias occur. The pyrite-bearing zone extends eastward through the pit floor to the opposite pit wall. 


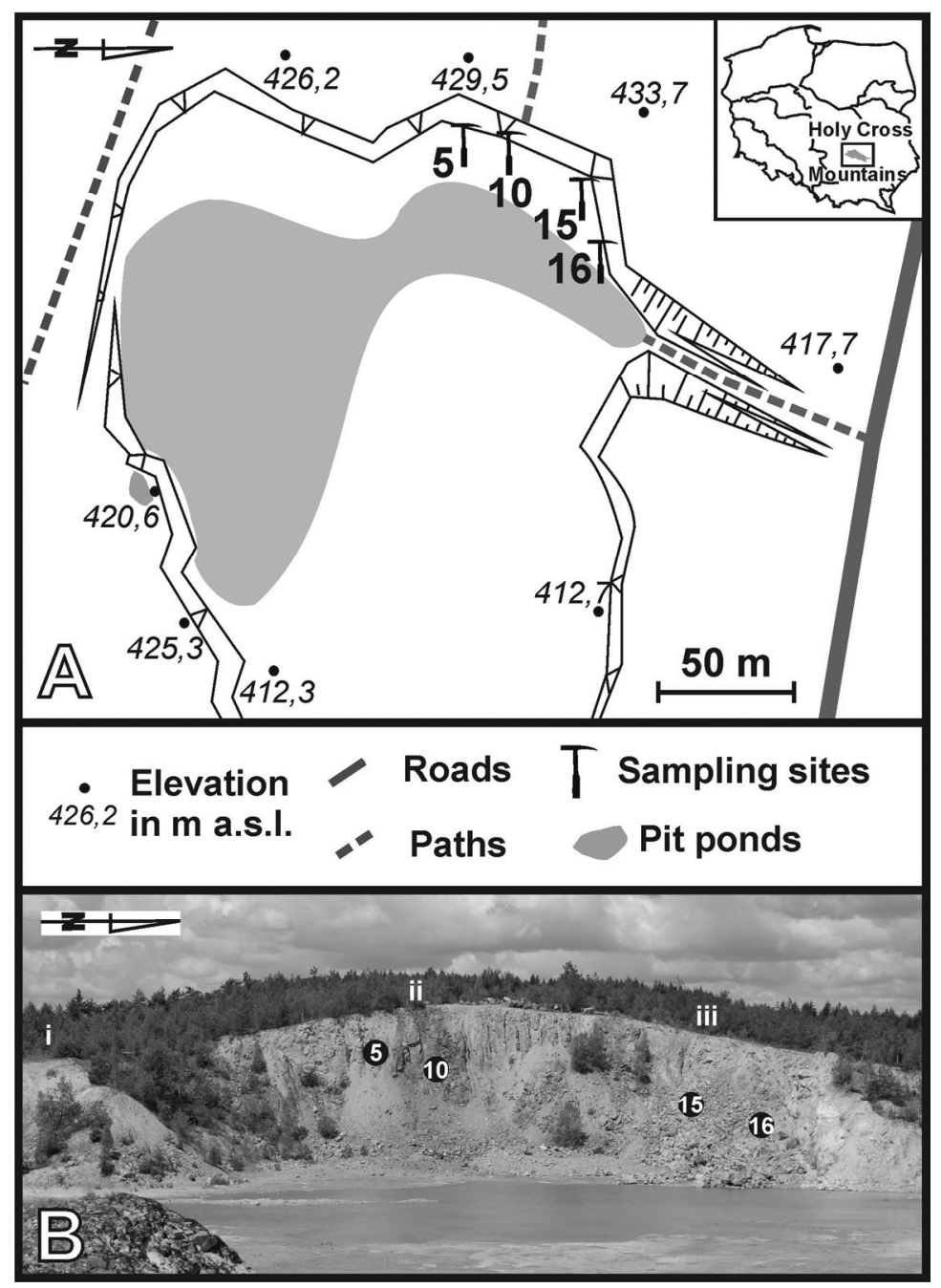

Fig. 1. (A) Location of the abandoned Podwiśniówka mine pit. (B) View of the western wall with a tuff/bentonitebearing quartzite series (i) in the south, a pyrite-rich quartzite-clayey shale series (ii) in the center, and a tectonically brecciated iron-quartzite series (iii) in the north. Samples from sites: 5, 10, 15, 16 are described in Fig. 2

\section{Materials and methods}

In total, 28 quartzite, shale, tuff and pyrite-quartz samples were collected from three rock series of the most exposed western pit wall. Locations of four xenotime-rich sampling points $(5,10,15,16)$ are presented in Figure 1A. Microscopic examinations were performed on thin polished sections using conventional optical methods in transmitted and reflected light (polarizing microscopes Axiolab Carl Zeiss and Nikon LV100 Pol). In addition, the study of these rocks was carried out with scanning electron microscopy (SEM; microscope LEO 1430; EHT $=15 \mathrm{kV}, \mathrm{WD}=19-22 \mathrm{~mm}$ ) using different techniques, i.e. 
quadrant back scattering detection (QBSD), secondary electron imaging (SEI) and cathodoluminescence (CL). Semi-quantitative chemical analyses of selected minerals were made with an EDS ISIS Detector (Oxford Instruments Ltd.). The samples were coated with carbon prior to SEM analysis. The SEM study was performed at the Electron Microscope Laboratory of the Polish Geological Institute in Warsaw.

\section{Description of samples}

The results of petrographical and mineralogical studies of host rocks in the Podwiśniówka quarry were described in more detail by Migaszewski et al. (2007a, 2008). They indicated that the quartzites consisted primarily of quartz, whereas the shales comprised muscovite and illite. Most of the shales also contain a considerable amount of aleuritic terrigenous and subordinate pyroclastic quartz grains. Smectite and kaolinite are scarce, and volcanic glass, chalcedony and feldspars occur only in trace amounts. The detrital accessory minerals are dominated by rutile and zircon, as well as scarce monazite, anatase and tourmaline. The crandallite series minerals also occur in trace amounts in all the rocks examined (Migaszewski et al. 2007b). In addition, the quartzites and subordinate shales of the central series (ii) reveal the presence of variable amounts of scattered and vein pyrite (Migaszewski et al. 2007a, 2008), accumulations of wavellite and variscite (Dumańska-Słowik et al. 2007), vein nacrite and jarosite, as well as a large variety of supergene minerals, including iron oxyhydroxysulfates and oxyhydroxides (e.g. schwertmannite, ferrihydrite, hydroxy-green rusts, goethite, and in places alunite, secondary jarosite and gypsum (Migaszewski et al. 2008).

\section{Results}

One of the most common detrital accessory minerals of the examined siliciclastic rocks is zircon $\left(\mathrm{Zr}\left[\mathrm{SiO}_{4}\right]\right)($ Fig. $2 \mathrm{~A}-\mathrm{H})$. Zircon occurs as subrounded-to-rounded grains reaching $160 \mu \mathrm{m}$ in diameter. Some exhibit complex zonation in QBSD images (Fig. 2A-C), but zonation in others is best observed in CL images (Fig. 2E).

In contrast, xenotime $\left.\left(\mathrm{Y} \mathrm{PO}_{4}\right]\right)$ forms pyramidal, dentate overgrowths on most of the zircon grains (Fig. 2A-E). In places, the xenotime rim is nearly complete (Fig. 2B, F). Some of the outer xenotime grain boundaries on contact with the matrix are somewhat rounded. Discrete xenotime grains are scarce in the samples examined. This evidence may suggest that specific nucleation conditions were required for xenotime growth. In general, the xenotime overgrowths vary in size from minute (about $1 \mu \mathrm{m}$ ) dentate crystals to larger prisms up to $50 \mu \mathrm{m}$ long and $20 \mu \mathrm{m}$ wide. In some places, the xenotime fills fractures within zircon grains (Fig. 2G). Some of the zircon grains contain minute inclusions of xenotime (Fig. 2D, E). In contrast to the zircon grains, the xenotime overgrowths generally display a delicate, irregular patchy-zonal microtexture (Fig. 2A-C, F, G).

In some places, the zircon/xenotime aggregates are partly coated by pyrite, which is scattered in quartzites of the central series (ii) (Fig. 2H). It is interesting to note that the xenotime overgrowths on detrital zircon also occur in hydrothermal pyrite veins. 

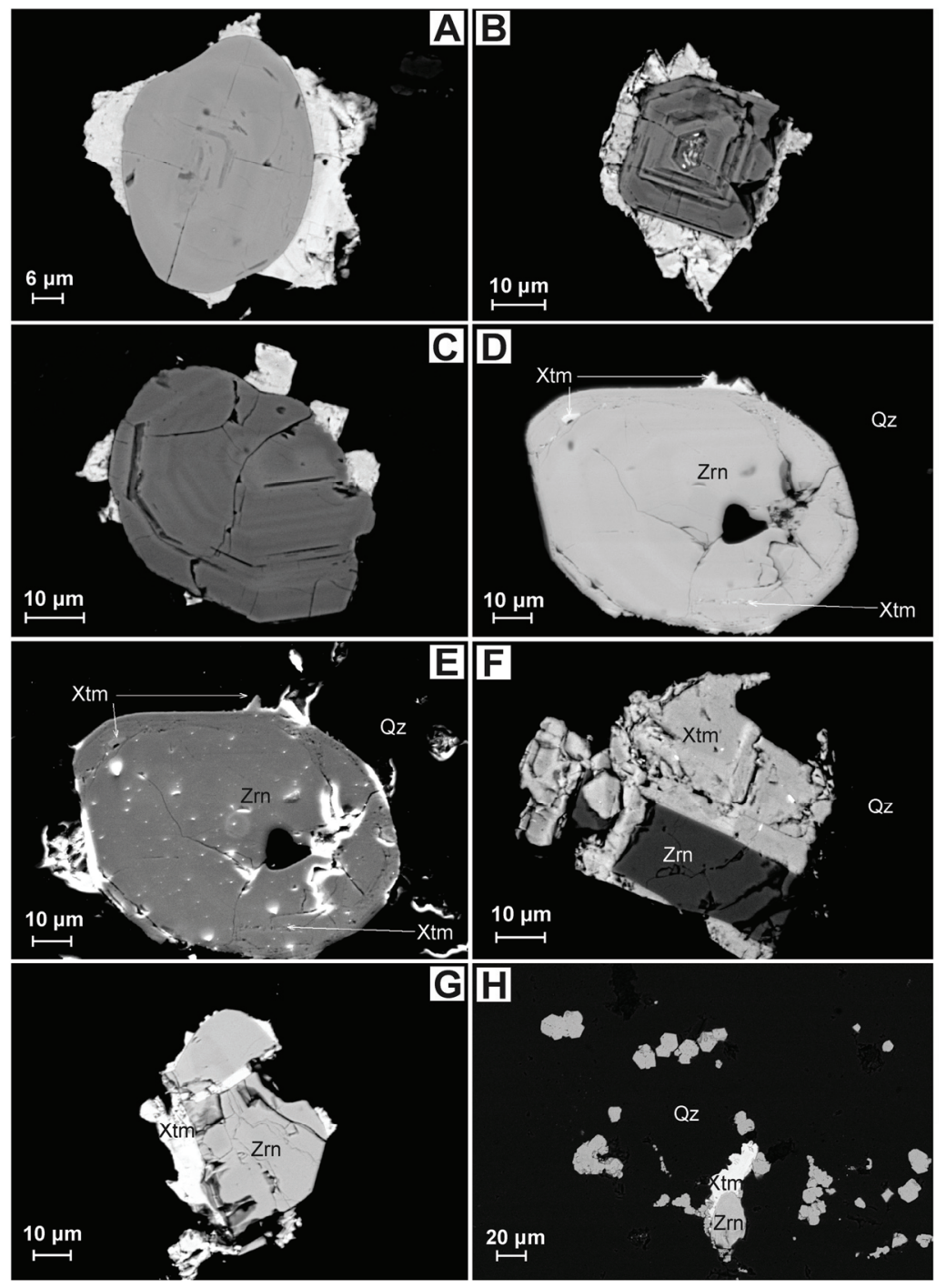

Fig. 2. SEM/QBSD/CL images. (A, B, C) Rounded to subrounded zonal zircon grains overgrown by minute aggregates of xenotime (showing a delicate irregular patchy-zonal microtexture, locally with dissolution marks) embedded in a quartz matrix of ferric quartzite (A, B - sample 15) and metamorphic quartzite (C - sample 16). (D, E) Subrounded zircon grain partly surrounded by minute tooth-like crystals of xenotime with somewhat rounded grain boundaries. Some of the pores and cracks in the zircon grain are infilled with submicroscopic inclusions of xenotime. Zonation of zircon is highlighted in a CL image (E). These accessory minerals occur in a quartz groundmass of quartzite (sample 5). (F) Zircon grains enveloped by a xenotime overgrowth showing a compositional patchy-zonal microtexture. The smaller zircon grain is almost entirely enclosed by the xenotime. These two minerals are embedded in a quartz matrix of ferric quartzite (sample 15). (G) Fractured zircon grain with xenotime overgrowths and fills exhibiting a delicate, irregular patchy-zonal microtexture (sample 15). (H) Irregular xenotime overgrowths on a rounded detrital zircon grain and scattered sub- and euhedral pyrite grains sited in a quartz matrix of quartzite. Some of the pyrite grains contain xenotime inclusions (sample 10). Abbreviations: Zrn - zircon, Xtm - xenotime, Qz - quartz 


\section{Discussion}

The microtextural relationships between zircon and xenotime indicate that the subrounded-to-rounded zircon grains are of detrital origin. In contrast, most of the outer surfaces of xenotime overgrowths reveal no rounded morphologies that preclude the transport of combined zircon/xenotime aggregates along with other detrital minerals. This evidence suggests that the xenotime precipitated in a sedimentary environment prior to cementation of quartz grains. It should be stressed that similar pyramidal overgrowths of early-diagenetic xenotime have been found in sandstones and other clastic rocks throughout the world (e.g. Rasmussen 2005). Somewhat rounded outer xenotime boundaries are scarce and may have been formed as a result of early-diagenetic dissolution by hydrothermal fluids.

The microtextural relationships between pyrite and zircon/xenotime aggregates also indicate that the xenotime formed prior to the pyrite (see also Fig. 5A in Migaszewski et al. 2007a). The apparent lack of xenotime and vein pyrite in the tuff-bearing series (i), compared to the other two series (ii and iii) exhibiting hydrothermal imprint (pyrite, hematite, nacrite, jarosite), may indicate that the xenotime also precipitated from hydrothermal fluids discharged from sea floor springs, not directly from seawater (Rasmussen 1996). This suggestion is also evidenced by considerable variations of the xenotime overgrowths in size and morphology, and their dominant irregular patchy-zonal microtexture. According to some authors (Kositcin et al. 2003), this is a characteristic signature of hydrothermal xenotime. These results seem to exclude the breakdown of other Y- and P-bearing phases in the sediments during diagenesis as a possible scenario (Rasmussen et al. 1998).

It is noteworthy that some tiny xenotime inclusions found in a few zircons are of different origin (Fig. 2D, E). It seems that these inclusions were overgrown by lowtemperature zircon (Hay, Dempster 2009).

\section{Conclusions}

From this study the following conclusions can be drawn:

1. Authigenic xenotime overgrowths on detrital zircon grains are a common feature of siliciclastic rocks in the Podwiśniówka area. The xenotime inclusions within some zircon grains are subordinate and represent a different genetic variety.

2. The xenotime overgrowths predate the formation of hydrothermal pyrite.

3. The xenotime is a product of early-diagenetic precipitation and crystallization in shallow-marine siliciclastic sediments. The main source of $\mathrm{P}$ and $\mathrm{Y}$ for this mineral may have been hydrothermal fluids discharged from sea floor vents.

Considering this, in the area examined the sea floor spring activity may have taken place directly after deposition of siliciclastics in the Late Cambrian, i.e. during the Caledonian sedimentary-diastrophic cycle.

\section{References}

Dumańska-Słowik, M., Heflik, W., Natkaniec-Nowak, L., \& Sikorska, M. (2007). Wavellite and variscite in the Cambrian sandstones from the Wiśniówka Duża quarry near Kielce. Przegląd Geologiczny (Polish Geological Review) 4, 287 (in Polish). 
England, G.L., Rasmussen, B., McNaughton, N.J., FLetcher, I.R., Groves, D.I., \& Krapez, B. (2001). SHRIMP U$\mathrm{Pb}$ ages of diagenetic and hydrothermal xenotime from the Archaean Witwatersrand Supergroup of South Africa. Terra Nova 13(5), 360-367.

Förster, H.-J. (1998). The chemical composition of REE-Y-Th-U-rich accessory minerals in peraluminous granites of the Erzgebirge-Fichtelgebirge region, Germany. Part II: Xenotime. American Mineralogist 83, 1302-1315.

Harlov, D.E., Prochazka, V., Förster, H.-J., \& Matějka, D. (2008). Origin of monazite-xenotime-zirconfluorapatite assemblages in the peraluminous Melechov granite massif, Czech Republic. Mineralogy and Petrology 94, 9-26.

Hay, D.C., \& Dempster, T.J. (2009). Zircon behaviour during low-temperature metamorphism. Journal of Petrology 50(4), 571-589. DOI:10.1093/petrology/egp011.

Hetherington, C.J., Jercinovic, M.J., Williams, M.L., \& Mahan, K. (2008). Understanding geologic processes with xenotime: Composition, chronology, and a protocol for electron probe microanalysis. Chemical Geology 254, 133-147.

Kosticin, N., McNaughton, N.J., Griffin, B.J., Fletcher, I.R., Groves, D.I., \& Rasmussen, B. (2003). Textural and geochemical discrimination between xenotime of different origin in the Archaean Witwatersrand Basin, South Africa. Geochimica et Cosmochimica Acta 67(4), 709-731.

McNaughton, N.J., Rasmussen, B., \& Fletcher, I.R. (1999). SHRIMP uranium-lead dating of diagenetic xenotime in siliciclastic sedimentary rocks. Science $285,78-80$.

Migaszewski, Z.M., Gałuszka, A., Hałas, S., Dołęgowska, S., Dąbek, J., Budzyk, I., \& Starnawska, E. (2008). Geochemistry and stable sulfur and oxygen isotope ratios of the Podwiśniówka pit pond water generated by acid mine drainage (Holy Cross Mountains, south-central Poland). Applied Geochemistry 23, 3620-3634.

Migaszewski, Z.M., Gałuszka, A., Pasławski, P., \& Starnawska, E. (2007a). An influence of pyrite oxidation on generation of unique acid pit water: A case study, Podwiśniówka quarry, Holy Cross Mountains (south-central Poland). Polish Journal of Environmental Studies 16(3), 407-421.

Migaszewski, Z.M., Starnawska, E., \& Gałuszka, A. (2007b). Gorceixite from the Upper Cambrian rocks of the Podwiśniówka mine pit, Holy Cross Mountains (south-central Poland). Mineralogia Polonica 38(2), 171-184.

Rainbird, R.H., Davis, D.W., Stern, R.A., Peterson, T.D., Smith, S.R., Parrish, R.R., \& Hadlari, T. (2006). Ar-Ar and $\mathrm{U}-\mathrm{Pb}$ geochronology of a late Paleoproterozoic Rift Basin: support for a genetic link with Hudsonian orogenesis, Western Churchill Province, Nunavut, Canada. The Journal of Geology 114, 1-17.

Rasmussen, B. (1996). Early-diagenetic REE-phosphate minerals (florencite, crandallite, gorceixite and xenotime) in marine sandstones: A major sink for oceanic phosphorus, American Journal of Science 296, 601-632.

Rasmussen, B. (2005). Radiometric dating of sedimentary rocks: the application of diagenetic xenotime geochronology. Earth-Science Reviews 68, 197-243.

Rasmussen, B., Fletcher, I.R., \& McNaughton, N.J. (2001). Dating low-grade metamorphic events by SHRIMP U$\mathrm{Pb}$ analysis of monazite in shales. Geology 29, 963-966.

Rasmussen, B., Buick, R., \& Taylor, W.R. (1998). Removal of oceanic REE by authigenic precipitation of phosphatic minerals. Earth and Planetary Science Letters 164, 135-149.

Rasmussen, B., Fletcher, I.R., Muhling, J.R., Thorne, NE, W.S., \& Broadbent, G.C. (2007). Prolonged history of episodic fluid flow in giant hematite ore bodies: Evidence from in situ U-Pb geochronology of hydrothermal xenotime. Earth and Planetary Science Letters 258, 249-259.

Richter, D.K., Krampitz, H., Görgen, P., Götte, T., \& Neuser, R.D. (2006). Xenotime in the Lower Buntsandstein of Central Europe: Evidence from cathodoluminescence investigation. Sedimentary Geology 183, 261-268.

Stanisławska, M., \& Michalik, M. (2008). Xenotime-(Y) veins in a Neoproterozoic metamudstone (Małopolska Block, S Poland). Mineralogia 39, 105-113.

Vallini, D.A., Rasmussen, B., Krapez, B., Fletcher, I.R., \& McNaughton, N.J. (2005). Microtextures, geochemistry and geochronology of authigenic xenotime: constraining the cementation history of a Palaeoproterozoic metasedimentary sequence. Sedimentology 52(1), 101-122.

Wark, D.A., \& Miller, C.F. (1993). Accessory mineral behaviour during differentiation of a granite suite: monazite, xenotime and zircon in the Sweetwater Wash pluton, southeastern California, U.S.A. Chemical Geology 110, 49-67.

Żylińska, A., Szczepanik, Z., \& Salwa, S. (2006). Cambrian of the Holy Cross Mountains, Poland: biostratigraphy of the Wiśniówka Hill succession. Acta Geologica Polonica 56(4), 443-461. 
